DNA AND THE POLITICS OF TRUTH IN SOCIALLY ORGANIZED LIFE

\author{
Julie Gustavs
}

Royal Australian and New Zealand College of Ophthalmologists

94-98 Chalmers Street

Surry Hills NSW 2010

AUSTRALIA

jgustavs@ranzco.edu

Stewart R. Clegg

School of Management

University of Technology Sydney

PO Box 123 Broadway NSW 2007

AUSTRALIA

s.clegg@uts.edu.au 


\title{
DNA AND THE POLITICS OF TRUTH IN SOCIALLY ORGANIZED LIFE
}

\begin{abstract}
We apply a representation of the double helix to explain how truth is managed in the social organization of life. One chain, representing context, is made up of the three materialities through which we move - discourses, time and space. The other chain, representing agency, comprises identity, distinct capitals and practices. The chains are fused by horizontal rods, which represent capillaries of power relating the elemental chains by binding, winding and tangling them together in various ways. The model offers an innovative tool for theorization of socially organized truth relations.
\end{abstract}

Keywords: DNA, power, truth, theory. 


\section{INTRODUCTION}

Truth and how it is managed is central to organisational life. The gap that this paper addresses is how, theoretically, we can examine how truth comes to count as such: what are some "thinking tools" (Bourdieu 1992) for social analysis of this central relation? We begin to answer this question from the realization that there is an undeniable patterning to how truth is managed which allows certain truths to be possible and others impossible in any given context. There is also the agency of individuals and organisations to account for in any sensemaking of truth: their jockeying for positions - working individually or in networks and alliances in their attempts to rally against, or support established truths. Integral to the answer to our question is also the knowledge that interactions between context and agency occur in a complex interplay of events in the everyday - some planned and others random. Given the complexity of such interactions any social theory seeking to answer the question of how truth is managed needs to allow the researcher the scope and flexibility to engage with, and explore, concepts which to the cursory gaze may seem contradictory: the organic, structure, complexity, patterning, random connections, order, as well as an allowance for individual and organisational level analysis. The purpose of this paper is to traverse such theoretical terrain and propose such a theoretical model.

We construct truth. In doing so, we react to events in our enacted environmental contexts; that is, the environment that we enact, using those grammars of motive, reasoning and language that we find available and which accord with those conventions we take for granted. Thus, we process what we take to be reality, often unconsciously, sometimes subconsciously. Reality is neither 'real' nor 'imagined', neither 'objective' nor 
'subjective', but a material construction of images constituted by enacted cues from our environments, and the circuits of power (Clegg 1989) in which we are embedded and of which we are aware - not necessarily coincident categories - and the material inscriptions that we sustain (Castells 2009: 139).

Seven analytically separable elements are co-present in our construction of truth: discourses, which provide us with ways of speaking about how we see, think, feel, hear and experience; time, which provides us with a sense of temporal relations between our selves, others and other things, that we experience phenomenologically, and space, which provides us with a sense of spatial relations situating others and other things in relation to our body self and objects. Materially, we move through space, time and discourses, not as solitary beings but as social beings whose disparate identities are brought into dynamic relations with each other.

Identity is never singular, never secure, always negotiated and thus dependent not only on what the self might posit but also on what the many other selves who are conscious of our identity constitute it as being. Our identities, we might say, are disciplined and oriented to by power relations, both negative and positive, as these are constituted through relations between self, others and objects in the material world. Identities are not static: they move and evolve through social time and social space and are expressed through various forms of discourse: in language, deportment, attire, and make-up generally. Space, time and discourses are organized and marshaled, it will be argued, through relating identities to resources - the various kinds of capital theorized by Bourdieu (1991) - with which the intentionality of self can be extended to networks of others and objects. 
Analytically, to organize, to bring different people together, to bind them with obligations, to have them work in teams, to orient them towards the achievement of goals, to harness them in a division of labor, for instance, requires the acknowledgment of various kinds of capital, which need to be determined empirically. In a market economy, it requires 'financial capital' to invest; as an economy of signs it also entails what Bourdieu (1991) refers to as composed of 'symbolic' and 'cultural capital'. Symbolic capital, for example, is any species of capital that is perceived through socially inculcated classificatory schemes the academic gown, the school tie an 'old boy' wears to denote that he is to be counted amongst those who attended a private school, the tag an adolescent sprays on the wall and so on. When an encoded embodiment of symbolic capital is mobilized as either a conscious or unconscious act to dominate, do injury, subordinate or exclude, symbolic violence is exercised. Symbolic violence can be done to oneself - as in the act of a prisoner who goes on a hunger strike or an asylum seeker in detention who stitches his lips as a symbol of his lack of freedom or right to speak. Symbolic violence can also be mobilized against the other to define identity. An example would be those Australian colonialists who carved their cattle brands over the sacred rock carvings of ancient aboriginal peoples. In this way, relations of the various kinds of capital (symbolic, financial and cultural) create distinct identities. Capital and identities, when combined, are capable of doing something or other; they are organized to produce specific practices. In social theory, we submit, that the truth relations of social life are composed of a double-helix of time, space and discourses entwined around identity, capital, and practices. What connect these elemental chains are capillaries through which flow relations of power. 


\section{(RE)PRESENTING THE DOUBLE HELIX}

Prior to elaborating our conceptual scheme of "thinking tools", we should first acknowledge the inspiration of their representation. Watson and Crick's (1953) model of the structure for Deoxyribose Nucleic Acid (DNA) was central to the success of their project being taken up by scientists and the broader society as that which is life, rather than its representation, (even though in Watson and Cricks' original paper they make it quite clear that the model of DNA that they proposed was originally conceived as a representation). We follow Watson and Cricks' example and use the representation of the double helix in an attempt to create our own persuasive text about how what is taken to be the truth constituting reality is managed in socially organized life. Central to our theorization is the presentation of two 'maps' of 'thinking tools' (Bourdieu 1992). The word 'maps' refers to the idea that when we 'map' we miss (Clegg and Hardy 1996). Ambiguities and multiple accounts arise. The term 'thinking tools' emphasizes the dynamic nature of the process of theorization and explicitly connects the activity of thinking with theory making in ways that stress the constructionist nature of any theoretical work. In our theorization we have two chains forming the shape of a double helix; however, rather than

phosphate-sugar chains we have one chain representing context, constituted by three defining contingencies of life and the other representing agency.

\section{Map I and Map 2 about here (the two images side by side)}

These maps flow from the fact that we are speaking, temporally and spatially specific, subjects. As subjects we live and die, move and speak: hence the contingencies of 
time, space and discourses define our being. We can only be in one place at one time; we cannot endure forever, and we leave marks of our coming to be and passing away through practices that are articulated discursively. Putting the two maps together creates our thinking tool for this paper: a representation of the DNA of the social organization of life as a double helix.

\section{Figure 1 about here}

Thinking tools are one way in which to 'delve into how things are socially organized, or put together, so that they happen as they do’ (Campbell and Gregor 2002:29). The main purpose of thinking tools is to help researchers examine how change in what counts as truth can occur, shifting the researcher's focus to a study of how knowledge is accomplished as a social fact. The beauty of the double helix as a thinking tool is not only that it conveys the idea of life itself but also that its shape is both regular and open; simultaneously it suggests patterning and contingency. Thus, in applying the metaphor to our own theorizing it conveys the idea that the two chains of agency and context intertwine in patterned and contingent ways, suggesting that their social effects both shape and are shaped by each other. Furthermore, the relationship between each individual contingency and chain is contingent rather than causal. Recognizing social relations as contingent rather than causal means shifting ones thinking from the consideration of 'certain, cold, unproblematic black boxes' to tracing the more fragile ellipses and sites of contestations which make up everyday life, whereby uncertainties abound as people make up what comes to count as true through decisions, engaging in controversies, and compete with one another (Latour 1987a: 4). 


\section{CAPILLARIES OF POWER}

What connect the chains of the double helix of social life are capillaries of power relations, of which there are four ideal types (Thompson 2008; we draw on this work for what follows). Discursively, all forms of social relations involve limited ways of organizing and disorganizing: these comprise the hierarchical, the individualistic, the egalitarian, and the fatalistically autonomous. Each of these is a way of disorganizing the other four and since each form of organizing requires its other to organize against, subversion is inevitable. Hence, power relations always call forth relations of resistance.

The hierachist - the adherent to and servant of hierarchy - is characterized by a preference for embeddedness in ranked and bounded groups with a stress on procedural rationality, while the individualist is committed to ego-focused networks and substantive rationality focused on calculations in the here-and-now. The egalitarian model is characterized by preferences for bounded and unranked groups and espouses critical rationality while those whose lives are mostly marked by exclusion from the resources of individualism, hierarchy and egalitarianism will tend to be fatalists with a rationality that basically accepts that whatever happens, will happen. These four rationalities are each oriented to distinct modes of action: collecting followers, customers or clients for individualists; racking up more sources of exclusion for the fatalist; gaining more rights and obligations for the hierarchist, and achieving more equal outcomes if you are an egalitarian. One who wants none of these things - who renounces the other ways of being in the world - becomes an autonomist with an immediatist rationality best served by withdrawal from all organized forms of solidarity. The autonomist tends to become a hermit. 
The three main ways of organizing in terms of discursively available rationalities produce different ways of striving to configure social truths: ego-focused groups (individualist patterning), bounded and ranked groups (hierarchical patterning), and bounded but unranked groups (egalitarian patterning). Hermits organize themselves in contradistinction to all three patterns, and fatalists are on the outside of all patterns: for them, "shit" just happens! No patterning is ever total; there will always be adherents of more than one pattern in any situation of organizing and disorganizing, and indeed, each needs the others in its environment to organize against if it is to be viable (requisite variety condition). It is this dynamic that sustains organizing/disorganizing as an autopoietic system in which disequilbriation moves between the different ways of getting things done in a swarm of complexity producing ordering without predictability, as well as surprise. Surprise is the crucial link-pin between social understandings and the worlds in which we live. If the worlds we experience do not confirm to the convictions of our solidarities we are going to be surprised!

If each mode of organizing can only be made sense of in terms of those others that it struggles against, then struggle - and thus power - is central to the schema as an emergent property of all social relations in self-organizing systems. Moreover, each way of organizing has a specific modality of power associated with it; the hierarchical and individualist seek to exercise power over to shape the other ways of organizing; the fatalist and egalitarian strive to articulate their power to resist other ways of organizing, while the hermit seeks to operate in a power void. How then are preferences formed in the different ways of doing things? They pre-exist those people who end up working with any of the 
ways of organizing; they are discursively given as modes of rationality. For instance, within the individualist solidarity the vocabulary of motive revolves around the competitive axis; forms of preference can only sensibly be performed in these terms. Being altruistic, for instance, would be to move from individualistic to egalitarian solidarity.

\section{BRINGING CONTEXT BACK IN}

\section{Truth is managed through discourses}

Discourses are visible in language forms but are also perpetuated through social practices and embedded in institutional structures. For Foucault (1972), discourses are equivalent to a cultural code, a system of thought, or as he put it in his earlier work, an episteme that a society values. Discourses can be thought of as 'serious statements' that organize knowledge and in addition are inseparable from knowledge. They determine the kinds of communicative practices that specific members of specific societies will engage in. Discourses act both to combine and to divide practices.

The formation of certain discourses and the easing out of currency of others is neither a linear nor cumulative process but subject to rules. A strong degree of patterning shapes which discourses are picked up and which are screened out, given the strength of the network of discourses that are created by a wide range of socio-political institutions in which the individual goes about their quotidian activity. Discursively these institutions hold the subject/object accountable in those terms that each counts as 'normal'. Rules that shape discursive formations (in addition to many other things) permit certain statements to be 
made while excluding or silencing other possible statements. Such a process of selection and screening out of discourses occurs at both a conscious and unconscious level.

Discourses provide us with ways to discuss locally situated 'truth games' which are both talked into and out of being in specific contexts. In his work on discourse and discursive formations, Foucault describes the mechanisms through which themes of discourse (discursive objects) become established and 'real' in public communication. Changes in discourse occur because justifications for organizing activity can be, and indeed are, constantly challenged. From a practical perspective what will be of central interest for empirical researchers is the ability to trace particular instances of discourse, to make connections between these instances, and to identify a particular discursive formation, especially as it comes into being. Think, for instance, of the sudden renaissance of the regulatory state in the wake of the crisis of neo-economic liberalism. The rapid interruption and disarticulation of discourses of the market provides a particular example of an instance where discourses shifted rapidly, providing evidence of a new 'truth game' coming into existence (albeit one that had been forgotten over the previous thirty years). Central to analysis of discourse will be temporal markers. Temporal markers are important because they help us to see both the continuities and discontinuities which occur throughout history as well as to explore what impact future projections have in determining what counts as truth. Thus, we take this as suggesting the necessity to couple our discursive analysis with a second contextual contingency - an analysis of time.

\section{Truth is managed through time}


Time is understood in terms of what constitutes past, present and future. As we know from Schutz (1967) these definitions are always contingent on the perpetually shifting here-andnow, even for large-scale time-reckoning systems, such as historical periodizations. Cumulative and evolutionary views see time as a singular, fixed entity, complete unto itself, 'hence independent from events' (Clarke 1990:142). Such a conception of time sees it as synonymous with the clock. In our theorization of time, the experience of time is not seen to be an objective fact but rather constructed locally and socially 'via networks of meaning'; thus, 'time is experienced differentially’ (Hassard 1996: 328, drawing from Heath 1956). As Chan and Clegg (2002:261) explain, one needs to work on the assumption that the past is not a 'fixed' and stable 'continent but a landscape constantly redrawn in terms of contemporary aesthetics, techniques, and concerns'. In this way, the assumption that a definite break with the past can be made is problematized. Any new practice is seen and experienced within the context of past practices. The past is seen to be reshaped from a particular 'now' position. We progressively reconstruct the past in order to serve the interests of the present.

To understand how concepts of the future can be analyzed to critique the present the phenomenologist, Schutz (1967:65) provides the concept of the 'future perfect' to explain how the analysis of time can incorporate future perspectives by examining 'action before its execution'. Schutz puts it that 'while the action has yet to take place it is phantasised as that which will have taken place, that is, in the future perfect tense as something already performed.' (Pitsis et al 2003 provide a strategic example of this from their research on projects.) Schutz's concept of future perfect, which provides a theoretical conception of 
how the future influences sensemaking of the present, complements Foucault's concept of genealogy whereby he shows, through detailed examination of past practices and beliefs, that different "truth games" determine what counts as truth throughout our cultural histories. Thus, drawing on Schutz's concept of 'future perfect' and Foucault's concept of genealogy is essential in our theorization of how truth is managed temporally: it provides us with a framework to critique the present "truth games" we are playing by rigorously examining those we played in the past and those we wish to play in the future.

\section{Truth is managed through space}

Scientists maintain that good science arrives at generalizable findings and laws divorced from the messiness of everyday life. We maintain that this 'isolation' misses 'something' and that this something is the spatial ordering of relations between people. In society we have come to see laboratories as scientists' claim they do in their formal accounts: linked with generalizability, objectivity and, by implication, truth and fact. But Latour and Woolgar (1979) have helped us to see things differently.

Latour and Woolgar (1979), in their evocative tale of Laboratory Life, portray the work that scientists do in the space of their laboratories as a social phenomenon, in contrast to its positioning in the dominant scientific literature as divorced from its social context. Based on over two years of watching and recording how scientists actually do science in practice, we come to see that 'normal science' is established through personal struggles over different versions of what is to be constructed as the truth; one version comes to be seen as legitimate with the result that others are seen to be 'false' or illegitimate and, as 
such, are eased out of currency. Thus, rather than being 'neutral', truth is integrally linked with the power to structure standing conditions within laboratory space. This point is reinforced by shifting our gaze to other isolated spaces, such as the 'isolation ward' in a hospital or 'isolation cell' in a prison, the materiality of isolation as a practice becomes clearer. It creates an environment that is separated from any element of contagion from the everyday world of messy things: dust, dirt, viruses, other people, and other things that would be out of place in a pristine and sanitized space. Furthermore, although laboratory experiments are the most obvious data collection techniques that isolate actors spatially, given that they occur in a special place - the laboratory - other techniques, such as interviews and surveys, also order the relations between researchers and researched. They isolate subjects within a research world whose relevancies are rarely shared by these subjects in their everyday life.

Space encompasses the materiality of embodied relations occurring in it. Shifts in how one conceives of space significantly shift the nature and focus of what is seen and not seen, what is taken to be important and unimportant. Researchers examining institutions, key stakeholders, their inter-relationship and forums for expression in situ approach space differently from those who abstract these properties. Orthodox geometrical, mathematical and scientific notions of space trace a 'scientific' space. This is a space shaped by Kant, who separated space from the gaze of empirical inquiry by maintaining that it 'belonged to the a priori realm of consciousness (i.e. of the subject) and partook of that realm's internal, ideal and hence transcendental and essentially ungraspable structure' (Lefebvre 1991:2). Transcendental conceptions of space enable the researcher to create abstracted patterns of 
relations in hierarchies, numbers and charts; they are not conceptions of space that require examination of the minutiae of spatial life, which we are proposing, as well as reflection on the social meaning that it carries. For example, in organizational analysis it may be important to recognize the back-room spaces hidden from the gaze of the customers, as well as the spaces an organization uses to represent itself to its public (Goffman 1959). In such spatial analysis it may also be important to establish who has an office and who does not, as well as aesthetic features, such as size, location, furnishings, architecture, and to ask where meetings are conducted, who they involve, how the participants dress, embody themselves, shift position, take liberties, do deference, and so on. Seen this way, the analysis of space involves extending beyond physical conceptions to include material, mental and social aspects (Lefvebre 1991). Furthermore, as Hernes (2004:5) explains, there are a multitude of 'sub-organizations' that are constantly being created both within and without the organization. In this way, he suggests many more spatial categories of concern, including both informal and formal ways in which members make meaning of the organizational spaces in which they operate. Because members make meanings space is not transcendent and ordered a priori.

Macro and micro spatial arrangements occur on one plane - rolling before us interconnected, interlinked, and contingent. Space is integrally linked with time - the past, present and the future. Space, rather than abstracted, is constituted through countless incidents and practices of everyday life, as one sees in Foucault (1977) and Goffman (1959). Foucault, like Bourdieu, stresses that space extends beyond physical boundaries such as walls. Foucault integrally links space with power and knowledge. Foucault shows 
us 'how institutional transformations are often the results of "body politics"', such as the shift from the deliberate inscription and marking of the body of pre-modern regimes of punishment to the modern concern with disciplining the body, soul and mind through tutelary regimes that organize bodies through timetables (Hernes 2004:60). Goffman (1959; 1961) was one of the first to take us inside these institutional spaces and show us theoretically and practically how the everyday language of signs, both spoken and gestural, inhabits and populates space with meanings. Next, we turn theoretical analysis to a discussion of the second map of thinking tools, concerned with 'bringing agency back' in.

\section{BRINGING AGENCY BACK IN}

Intertwined with the three contextual and structural contingencies of discourses, time and space are a further three contingencies - identity, capital and practices, which make up the

processes of agency that individuals and groups of subjects and objects deploy in determining how truth comes into being. Drawing on the theorization of Callon (1986), Latour (1994), and Law (1986) we dissolve the boundaries between the subject and object as well as the living and the non-living, such that not only humans but also everyday objects are potent actors having agency within a field. Therefore, we shift our language from the Foucauldian terminology of 'subject' and 'subjectification' to Latourian terms 'agent' and 'agency' to describe the processes by which both objects as well as subjects have a part to play in determining what counts as true within a field.

Choices that are made in daily life about which connections will be taken up or not, as well as their interpretation, the actions taken, and their outcomes, are central to the ways 
in which agencies constitute local truths. These choices and their interpretation and effect are contingent rather than causal. Seen in this light, what counts as truth is not determined by the intersubjective agency of individual agreements as coherence, or by the agreement of these coherencies in correspondence with objects, but is rather the result of heterogeneous networks of connections as well as networks of objects and subjects - what Czarniawska (2009) calls 'action nets'. Agents are strategists, hence they are neither reducible to a self-defining agent (symbolic interactionism) nor a rule-guided agent (ethnomethodology). Rather agents work within a given historical context; thus, not all options will be available to agents at any one time. An agent is a product of and produces the historical and social context in which s/he operates - which we identify in terms of the contingencies of identity, capital and practices.

The examination of identity or identities involves coming to terms with representations of both who we are and who we are not, institutionally and individually. Conceptions of capital are brought to light through attention to questions of 'what is and is not at stake', 'valued', 'of interest' or 'counts' for us in a particular arena. Thus, capital is much more than mere money, as Bourdieu recognized: it is also knowledge, social, and other forms of asset. The examination of practice(s) is concerned with perspectives of both what we do and do not do. Importantly, in using such an approach, researchers do not define ways of seeing conceptions of identity, capital and practice in their own terms but rather seek to examine those that subjects and organizations themselves both construct and enact in the 'everyday'.

Truth is managed though identity 
Identity is made up by what an agent is and what an agent is not taken to be by meaningful actors. The agent might be a person, a machine, or an organization; conceptions of agency cannot be taken for granted. Rose (1996:172) suggests that the subject is constituted through a process of 'subjectification', an active rather than a passive process, whereby 'subjects ... are nothing more or less than the changing connections into which they are associated.' Rather than conceptions of identity being 'unproblematic', and 'essentialist', framed as 'fixed', 'core', 'stable' and 'true', subjects' actions produce multiple conceptions of selfhood or identities within a given historical framework of power/knowledge. A subject could, for example be a mother, lover, worker, daughter, atheist, middle-class, white, human relations manager, and so on. Equally, for an organization its identity may be multiple: a local family enterprise, a bank, a global corporate partner, an employer, a corporate sponsor, and so on. The networks of connections that make up identity suggest a 'profusion of spaces and identities and the permeability of boundaries in the personal body and in the body politics' (Haraway 1991:170). According to this view of identity, there is no 'true' identity. Rather, the individual's or organization's concept of identity goes beyond their own sense of themselves to take into consideration the perceptions of others with whom they interact within their social milieu. Identity is a matter of performance - 'a continuous process of narration where both the narrator and audience formulate, edit, applaud and refuse various elements of the constantly produced narrative' (CzarniawskaJoerges 1996b: 160).

Identity is heterogeneous and premised on difference. Sveningsson and Alvesson (2003) talk of the importance of 'anti-identity' whereby organizations or individuals seek to 
distance themselves from certain characteristics and in this way define themselves by making it clear that which they are not (Kunda 1992; Duckerich et al. 1998). The heterogeneity of identity as being constituted by networks of subjects and objects also suggests that questions of identity need to be explored as multiple interminglings within the organization studies literature: organizational, professional, individual, social, and so on. Additionally, relationship between identities should be sought rather than conceptualized separately. Organizations are not 'boxes leading their own lives’ (Hernes 2004:18) but rather are characterized by 'dynamics' which 'consist of continually emerging processes rooted in existing organizational arrangements' (Hernes 2004:21) or, as Chia (1995:601) describes them, 'implicit assemblages of organizational actions and interactions.' Equally, there is interplay between the individual and organisational identity through an employee's engagement in, and commitment to organizational priorities and outcomes. This is not unitary but rather seen in the light of her being a member 'of a number of groups ... the organization itself, divisions, departments, or work teams as well as management teams, project teams, professional groups, or other informal groups' (Paulsen and Hernes 2004:14).

In summary, in taking how the identity of agents is made up into consideration we need to trace who and what, within our field of analysis, is involved in heterogeneous networks of connections of subjects and objects. Such an analysis is complex because, as we have seen, conceptions of identity are multiple. They include who we are and who we are not, comprising intermingled analysis, entanglements of power (Clegg et al 2006).

\section{Truth is managed though capital}


Central to our understanding of the subject as a strategizing agent is our exploration of the second thinking tools making up agency - capital. Capital means consideration of that which 'counts', is 'at stake', 'of interest', or 'valued' in a particular field. Bourdieu (1992:111) argues that 'a capital does not exist and function except in relation to a field'. In order to clarify the specific forms of capital that are valued in a field one needs to interrogate tacit rules and regularities specific to the 'logic of the field' (Bourdieu 1992:99). Bourdieu stresses that a particular institution or individual may be predisposed to focus on one or more forms of such capital in a field. The different forms of capital have different degrees of liquidity - that is the degree to which they may be transformed into other forms of capital; differing rates by which they can be exchanged for other forms of capital, and differing susceptibility to attrition - through loss, flight or inflation. He maintains that capital should not be considered as something tangibly possessed, or exclusively defined as a financial resource. He talks of various types of capital including 'social', 'intellectual', 'cultural’, and 'symbolic' capital. However, Bourdieu stresses that such types are examples only and to ascertain what form of capital is valued at either an individual or organizational level one needs to engage in empirical work rather than deciding that which it constitutes $a$ priori. He goes on to explain that the relationship between capital and field can be compared to the trump card in a game. The metaphor works in the sense that

\footnotetext{
Just as the relative value of cards changes with each game, the hierarchy of the different (types) of capital ... varies across the various fields... There are cards that are valid, efficacious in all fields - these are the fundamental (types) of capital - but their relative value as trump cards is determined by each field and even by the successive states of the same field (Bourdieu 1992:98).
} 
The theorization of capital has been taken up in a number of arenas, including social theory, policy frameworks and, to a lesser extent, directly by management practice. In the literature one reads of proponents of 'social capital' (Baron et al. 2000; François 2002; Grootaert and Van Bastelaer 2002; Onyx and Leonard 2001) or 'intellectual capital' (Edvinsson and Malone 1997; Stewart 1997) or 'human capital' (Thurow 1970; Schultz 1971), rather than theorists who seeks to find the interconnection between each form of capital as well as the implications that the favoring of one form of capital within decisionmaking processes has for the use of other forms of capital. However, interestingly the various forms of capital are often discussed as separate entities and thus determined a priori rather than seen as possible lenses through which choices are made as to what is valued in a particular field. Thus, in such research, types of capital are not determined in relation to the field under investigation, as Bourdieu proposed.

In using the concept of capital as one of the 'thinking tools' in our theorizing of how agency comes into play within a field, we explore what is 'at stake' or valued in a field empirically and thus we return to Bourdieu's original project of capital as a loose term which needs to be determined in relation to the fields of interest to the investigation. Analyzing what is 'at stake' or 'valued' in a field is central to understanding agents as strategizing rather than cultural dopes.

\section{Truth is managed though practices}

Finally, truth is managed through practices - what one does and does not do. Ethnomethodology is central to our understanding of practice in that it focuses on how 
members demonstrate understanding or capacity to go on in everyday activities rather than what they may say about practice. Boden's (1994: 79) ethnographic examination of meetings, for example, shows that 'direct observation of organizational behavior and work practices in situ provides quite distinctive insights into such issues as rationality, effective management, decision making and the like.' Similar to Boden's analysis of practice, with its focus on data collected from the observation of everyday activities and the recording of talk in the workplace rather than the collection of data from less authentic sources such as interviews or focus groups, is the situated learning (Brown and Duguid 1991) and communities of practice literatures (Lave and Wenger 1991; Wenger 1998). Brown and Duguid's (1991) classic study conducted at Xerox Park shows us how photocopy service technicians go about their practice of repairing photocopy machines. The study powerfully demonstrates that practice entails far more than the following of rules. A key finding of the research was that the knowledge that service technicians used to accomplish the repair of a photocopy machine went far beyond their technical manuals: the espoused rule governed modes of practice. The service technicians had informal knowledge, circulated mainly by word of mouth, of their own instances of problem solving strategies based on their experience. The technicians also engaged in professional dialogue with technical specialists. The knowledge that led to their capability to repair the machines was collective, convergent, and coherent. Seen in this way, practice is the 'acquiring, sustaining and changing through collective actions, of the meaning embedded in the organization's cultural artifacts' (Cook and Yanow 1993:384), thus, pointing to the inadequacies of conceptualizing practice as exclusively rule-based and rational. Equally, in the communities of practice literature Wenger (1998), focusing on the work of claims processors in an 
insurance firm, points to the disparity between the 'individual, asocial, linear view' (Wenger 1998:46) that senior managers held of the job and the actual reality of doing claim processing work. Wenger puts it that seeing practice in terms of a 'community of practice' shifts understanding of practice from a utilitarian, linear and rational approach to an understanding of practice which acknowledges that it is 'both the explicit and tacit. It includes what is said and what is left unsaid; what is represented and what is assumed' (Wenger 1998:47).

Flyvbjerg (2001:24) establishes the problematic nature of rational, rule-based modes of thinking in relation to practice when he points out that there is nothing intrinsically wrong with rules and rationality. Rather, the problem resides in how they have 'been elevated from being necessary to being sufficient and even exclusive' with the result that academics and practitioners have 'become blind to context, experience, and intuition'. To demonstrate this point, Flyvbjerg (2001:10) draws on a compelling research study, conducted in the United States, whereby a number of respondents, including students with limited experience of cardiopulmonary resuscitation (CPR), instructors as well as expert paramedics, were asked to watch a video of six people administering CPR to victims of acute heart failure. Respondents were asked to identify the person that they would prefer to be resuscitated by, if they were the victims of acute heart failure. Five of the people in the video were students and only one was an expert paramedic. The results of the study showed that ninety percent of the expert paramedics were able to identify the one expert paramedic in the video, however counter-intuitively, only thirty percent of the instructors, compared to fifty percent of the students, were successful in the task. As an explanation of the poor 
performance of the instructors in this study, Flyvbjerg proposes that it relates to the way in which the instructors construct and enact their own professional knowledge and practices in contrast to expert practitioners. In viewing the videos, the instructors were more likely to favor those individuals who exemplified the 'rule-governed behaviour' that made up their approaches to teaching CPR. Given that the students on the videos were in the process of learning CPR from such teaching techniques, they were more likely to exemplify such rulebased behaviour. In contrast, experts often adopt approaches to practice that go beyond following the rules. They 'just do what works' (Flyvbjerg 2001:17). The significance of drawing on such research in the context of this argument is that it provides a damning critique of rational rule-based thinking and emphasizes that to comprehend the broader perspective of human activity on which expert performance is based one needs to look beyond the rules (Flyvbjerg 2001:22).

In the context-independence of 'normal science' environments are carefully controlled and contrived so that all features of the context, other than those admitted as controlled variables, are screened out for the purpose of discovering the generalizable rules that govern a particular phenomenon. Rather than acknowledging and engaging with the complexity of organizational life, proponents of the normal sciences screen out the voices of agents in the field, respecting protocols of research practice rather than showing a respect for the protocols and practices of the everyday life to which they attend. Foucault adds significantly to our understanding of practices by focusing on what he saw as constituting 'borderline experiences’ (Foucault 1997a: 152). By focusing on the borders what counts as crime in relation to the law, or what counts as mental illness in relation to 
sanity and good health, or what counts as the exact point at which life is extinguished - one can trace points of rupture in relation to various systems - the legal system, the prison system, the health care system and so on, and in this way one is able to make assertions about how a particular practice came to be constituted as truth.

In summary then, in examining practice we propose that the focus should be on what actors do and do not do in their everyday life rather than focusing on what they say they do in research protocol intensive settings such as an interviews or surveys. Focusing on what people do in the everyday allows researchers to document the ways in which actors operate beyond the rules and how they strategize truth into reality. Foucault's technique of examining practices which lie on the borderline of a particular field are particularly instrumental in helping us to see how practices are constructed as social facts, in other words it helps us to ascertain how such practices came about, how they were established and justified, what these practices consist of. In the final section of this paper we will show how the two maps of thinking tools are fused in capillaries of power.

\section{BRINGING CONTEXT AND AGENCY TOGETHER}

Earlier in this paper in our section on '(re)presenting the double helix' we stressed that the two maps of thinking tools are not to be read as static and linear but rather dynamic and inter-related. The glue that holds them together is power. Power is fluid and connected. It operates as a 'network of relations' between people, objects, and forces. Seen in this way power is neither something exclusively determined by specific contextual conditions nor is it directly attributable to a person, who has power over others. Hence, examination of the 
way in which power influences how truth comes to be seen as such is less concerned with 'taking sides, identifying who has more or less of it, as seeking to describe its strategic role - how it is used to translate people into characters who articulate an organizational morality play’ (Clegg and Hardy 1996: 378).

\section{Truth is managed through power}

According to Foucault every society has certain 'politics of truth', which operate as the rules within which truth games are played out. Foucault shifts the focus of his inquiry from the traditional truth concern of what is truth to an examination of how truth is constituted. Foucault traverses innovative theoretical territory in seeking answers to the question of how truth is constructed. It involves examining who is creating history, pointing to questions about the nature of language and writing itself. By pointing out that 'power is always present' Foucault (1988d: 11) stresses that it is meaningless to try to analyze truth outside power: power produces truth and truth produces power. Furthermore, Foucault stresses that rather than being 'possessed', power is not the 'privileged', 'acquired' or 'preserved' artifact of the dominant order but the overall effect of its 'strategic positioning' and such positions are continually contested. Thus, for Foucault, power, and its relation to truth, has no essence, power is not situated in any 'particular place; power is not reducible to institutions' from which standpoint truth can be decreed (Foucault 1980: 92). Power is at its most effective when it is linked with persuasive positive attributes such as passion, feelings of belonging, commitment and love, built into the very capillaries of social life, rather than rather than the negatives of domination and repression (Chouliaraki and Fairclough 1999: 90). 
As part of the technologies of persuasion we can see the emergence of practices and rationalities that instill in people the capacities for self-regulation and self-governance, according to both formal and informal rules of conduct and expectations that show the 'way things are' and the 'way they should be'. As we have proposed, following Thompson (2008), there are a limited number of these in ideal typical terms. Thus, in examining the role that power plays in constituting truth as researchers we need to trace the complex interplay of ‘seductions, associations, problematizations and machinations' (Rose 1996: 56) by which specific truth regimes are maintained, contested and overturned. In Foucault's terms we need to unsettle the taken for granted nature of why a certain way of making things problematic appears at a given point in time (Foucault 1997a: 165). Or, in Thompson's (2009) terms, why is it that there are tendencies to specific configurations of hierarchical, egalitarian, individualist, and fatalist thinking, organizing and disorganizing?

\section{CONCLUSION}

In terms of formal properties of discourses time, and space, as embodied features of the ways in which we live our lives (Lakoff and Johnson 1999), what is taken to be local truth, and how it is managed, shifts according to context. We see agency as always intermingled and intermingling in analysis. It is micro and macro. It exists at an institutional level, a group as well as at an individual level. Talk of agency involves concepts of identity, capital and practices - defining who agents are and are not, what is and is not at stake, and finally, what agents choose to do and not do. Finally, it is power that constitutes the capillaries that bind and through which vitalism flows, not just as a rational calculus but also involving the 
full gamut of passions, interests, and emotions - full of fear, loyalty, trust, betrayal, respect, pride, greed, ambition, deception and love - the whole human comedy ${ }^{1}$.

Translation of meaning requires a representation that allows for ongoing conversations: conversations which open up debate rather than seal them off, allowing space for ambiguities rather than anchoring them in probabilities with little or no space

\footnotetext{
1 Although not observed closely at first hand, yet carefully observed through its various forms of representations, current political events in our country provide a key example. Politics is one of the most tribal of activities in modern liquid societies. Parties seek to sustain solid identities that differentiate them from each other. Parties seek to establish their side of politics, and their associated truths, in power, despite all the compromises and negotiations that blur identity in democratic politics. Using the example of a political party, and its response to contagion and unanticipated events, in the shape of the global financial crisis (GFC), we can demonstrate the ways that the thinking tool of the model might be used in an indicative way. Just before the full import of the global financial crisis became apparent, in November 2007, government switched from conservative to social democrat rule in Australia. The subsequent crisis proved an exemplary test of thinking tools. Hitherto, balanced budgets were good and debt was to be avoided at all costs. The truths of monetarism that had been circulated extensively by bodies such as the IMF, which always specified cutting expenditure and conditional packages (Stiglitz 2005), were acknowledged across the mainstream political spectrum of both conservatives and democrats. Nonetheless, these truths were rapidly overthrown as the GFC unfolded in favor of government delivering a stimulus package through cash grants to citizens and grants to all first home buyers as well as through infrastructural investments, most notably a high-speed broadband network and the provision of extensive schools building program that, as a percentage of GDP, were greater than anywhere else other than China. The arguments against doing this were evident: building up budget deficits in the hereand-now would prefigure future governmental indebtedness that it would be irresponsible to develop. The power effects of changed flows of power relations were immediately apparent: all of these modes of power entailed egalitarian forms of organizing. The benefits flowed universally to all categories of identity determined as beneficiaries; respectively, first home-buyers; schoolchildren, teachers and schools, and citizens. There were significant temporal shifts as well. Temporality shifted from a focus on the immediacy of balancing the budget in the here-and-now to a longer term deficit-financing on Keynesian lines; spatially, the role of the state was greatly expanded into areas of economic management that had previously been abrogated to markets. In identity terms the financial agents of monetarism were castigated as the villains causing the crisis, in a key essay written by the Prime Minister, Mr. Rudd (2009). Capital shifted from being thought of principally in financial terms to accommodating social capital: infrastructure projects were rated not just in terms of being financially viable but also in their capability for building crucial social capital through providing better schooling, housing, transport etc. The power effects of the changing capillaries are evident: the brunt of structural readjustment is usually borne by the working class in IMF reforms as state services are cut and wages depressed to balance budgets; in this case the level of unemployment has increased but not by very much compared to other OECD countries. It sits at 5.8\% at the time of writing (September 2009), a statistic largely achieved by a decline in the number of full-time and a rise in the number of part time jobs, changing identities in terms of work relations. Actual time worked has been cut back significantly with no effect on the unemployment figures but accelerating the number of those underemployed. The identity of being employed changed dramatically for the more vulnerable in the labor market - but not in the binary terms that are usually advocated whereby the reserve army of the unemployed swells as a buffer for absorbing crisis.
} 
for alternative ways of thinking, talking and being. In his distinction between the modernist 'legislator' and postmodern 'interpreter' Bauman makes a similar point (Bauman 1987). For Bauman, the interpreter is concerned with 'translating statements, made within one communally based tradition, so that they can be understood within the system of knowledge based on another tradition'. He maintains that for this to work their needs to be a 'deep engagement' with the 'alien system of knowledge from which the translation is to be made.' Attention is also given to the maintenance of a 'careful balance between the two conversing traditions' to ensure that the intended 'meaning' remains 'undistorted' and is 'understood' (Bauman 1987:5). Actors, as agents, shape their existence through the actions that they take. However, actors as agents also shape and are shaped by the contexts in which they operate: not everything is possible at any given time, or in any space, nor is every kind of discourse able to be uttered in a given field. Furthermore, the scope of contextual possibilities does not remain static. It is complex, contingent and dynamic. Detailed and careful macro and micro observations of everyday life the empirical work of living with (metaphorical) the tribe, is required. The model of the DNA of truth in social organizational life seeks to capture this life blood. 


\section{BIBLIOGRAPHY}

Baron, Stephen, John Field, and Tom Schuller

(2000) Social capital: Critical perspectives. Oxford: Oxford University Press.

Bauman, Zygmunt

(1987) Legislators and interpreters: On modernity, post-modernity and intellectuals. Cambridge: Polity Press.

Boden, Deidre

(1994) The business of talk: Organization in action. Cambridge, UK: Polity Press.

Bourdieu, Pierre

(1991) Language and Symbolic Power, Cambridge, MA: Harvard University Press.

Bourdieu, Pierre, Wacquant, Loic J.D.

(1992) An Invitation to Reflexive Sociology, Chicago, University of Chicago Press

Brown, John S. and Paul Duguid

(1991) 'Organizational learning and communities of practice: Towards a unified view of working, learning, and innovation’. Organization Science, 2: 40-57. 
Callon, Michel

(1986) 'Some elements of a sociology of translation: Domestication of the scallops and the fishermen of St Brieuc Bay’ in Power, action, belief: A new sociology of knowledge. John Law (ed), London, Routledge, , pp.196-223.

Campbell, Marie and Frances Gregor

(2002) Mapping social relations: A primer in doing institutional ethnography. Aurora, Ontario: Garamond Press.

Casey, Catherine

(1995) Work, self and society: After industrialism. London: Routledge.

Chan, Andrew, and Stewart R. Clegg

(2002) 'History, culture and organization studies'. Culture and Organization 8/4: 259-273.

Chia, Robert

(1995) 'From modern to postmodern organizational analysis'. Organization Studies 16/4: 579-604.

Chouliaraki, Lile, and Norman Fairclough

(1999) Discourses in late modernity: Rethinking critical discourses analysis. Edinburgh: Edinburgh University Press. 
Clarke, Peter

(1990) 'Chronological codes and organizational analysis' in The theory and philosophy of organizations: Critical issues and new perspectives. John Hassard and Dennis Pym (eds), London: Routledge, pp.137-166.

Clegg, Stewart R.

(1989) Frameworks of power. London: Sage.

Clegg, Stewart R., David Courpasson, and Nelson Phillips

(2006) Power and Organizations, Thousand Oaks, CA: Sage Foundations of Organization Science.

Clegg, Stewart R., and Cynthia Hardy

(1996) 'Representations', in Stewart Clegg, Cynthia Hardy and Walter Nord (eds); Handbook of Organization Studies. London, Sage, pp. 676-708.

Cook, Scott D.N., and Dvora Yanow

(1993) 'Culture and organizational learning’. Journal of Management Inquiry 2: 378-90.

Czarniawska, Barbara

(2009) A Theory of Organizing, Cheltenham: Edward Elgar. 
Czarniawska-Joerges, Barbara

(1996b) 'Autobiographical acts and organizational identities' in Understanding Management. Stephen Linstead, Robert Grafton-Small and Paul Jeffcutt (eds), London: Sage, pp. 157-171.

Edvinsson, Leif, and Michael S. Malone

(1997) Intellectual capital: Realizing your company's true value by finding its hidden brainpower. New York: Harper Business.

Flyvbjerg, Bent

(2001) Making social science matter: Why social inquiry fails and how it can succeed again. Cambridge: Cambridge University Press.

Foucault, Michel

(1970) The order of things: An archeology of the human sciences. London: Tavistock.

Foucault, Michel

(1972) The archaeology of knowledge and the discourse of language, New York: Pantheon Books. Foucault, Michel

(1977) Discipline and punish: The birth of the prison. London: Penguin

Foucault, Michel 
(1980) 'Two Lectures', trans. Kate Soper, in Colin Gordon (ed.) Power/Knowledge: Selected Interviews and Other Writings 1972-1977, New York: Patheon Books, 78-108. Originally published in Microfisica del Potere, ed. Alessandro Fontana and Pasquale Pasquino. Torino: Einaudi, 1977. These two lectures were given at the Collège de France in January 1976.

Foucault, Michel

(1984) The history of sexuality volume I: An introduction. New York: Vintage. Originally published in English translation in 1978, New York: Pantheon Books. Cf. Michel Foucault. La Volenté de Savoir. Paris: Editions Gallimard, 1976.

Foucault, Michel

(1988a) Madness and civilization: A history of insanity in the age of reason. New York: Vintage. First published in English translation in 1965, New York: Pantheon Books. Originally published as Histoire de la folie à l'âge classique. Paris: Plon, 1961.

Foucault, Michel

(1988b) 'Truth, power, self: An interview with Michel Foucault' - Oct 251982 in Technologies of the self: A seminar with Michel Foucault. Luther Martin, Huck Gutman, Patrick Hutton (eds) (1988), 9-15. London: Tavistock.

Foucault, Michel 
(1988c) 'The dangerous individual' in Politics, philosophy, culture. Interviews and other writings 1977-1984. Lawrence D. Kritzman, (ed), 125-151. London: Routledge Press. Address to the Law and Psychiatry Symposium at York University, Toronto (1978). Originally Published International Journal of Law and Psychiatry 1 (1978), 1-18

Foucault, Michel

(1988d) Luther H. Martin, Huck Gutman, and Patrick H. Hutton (eds), Technologies of the Self: A Seminar with Michel Foucault, London: Tavistock.

Foucault, Michel

(1997a) 'What our present is' in The politics of truth. Sylvére Lotringer (ed), 147-168. New York: Semiotext(e).

Foucault, Michel

(1997b) ‘Subjectivity and truth’ in The politics of truth. Sylvére Lotringer (ed), 171-198. New York: Semiotext(e).

François, Patrick

(2002) Social capital and economic development. New York: Routledge.

Goffman, Erving

(1959) The presentation of the self in everyday life. New York: Doubleday Anchor. 
Goffman, Erving

(1961) Asylums. New York: Doubleday Anchor.

Grootaert, Christiann and Thierry Van Bastelaer

(2002) The role of social capital in development: An empirical assessment. New York: Cambridge University Press.

Gustavs, Julie

(2004) Working the Knowledge Game? The Power of the Everyday in Managing Truth in Organisations. PhD Thesis. UTS i-Research.

Haraway, Donna J.

(1991) 'A Cyborg manifesto: science, technology and socialist feminism in the late twentieth century' in Simians, cyborgs and women: The reinvention of nature. London: Free Association Books, pp 149-181.

Harker, Richard, Cheleen Mahar, and Chris Wilkes

(1990) An introduction to the work of Pierre Bourdieu: The practice of theory. London: The Macmillan Press.

Hassard, John 
(1996) 'Images of time in work and organization' in Handbook of Organization Studies.

Stewart R. Clegg and Cynthia Hardy. London: Sage.

Haugaard, Mark

(1998) The constitution of power: A theoretical analysis of power, knowledge and structure. Manchester: Manchester University Press.

Heath, Louise R.

(1956) The concept of time. Chicago: University of Chicago Press.

Hernes, Tor

(2004) The spatial construction of organization: Advances in organization studies. Amsterdam: John Benjamins Publishing Company.

Kornberger, Martin, Stewart R. Clegg, and Carl Rhodes

(2005) ‘Learning/becoming/organizing’. Organization 12/2: 147-167.

Kunda, Gideon

(1992) Engineering culture. Philadephia: Temple University Press.

Lakoff, George, and Mark Johnson 
(1999) Philosophy in the flesh: The embodied mind and its challenge to western thought. New York: Basic Books.

Latour, Bruno

(1987a) Science in action. Cambridge Mass.: Harvard University Press.

Latour, Bruno

(1994) ‘On technical mediation-philosophy, sociology’. Genealogy 3/2 (Fall): 29-64.

Latour, Bruno, and Steve Woolgar

(1979) Laboratory life: The social construction of scientific facts. Beverly Hills: Sage.

Law, John

(1986) 'On power and its tactics: A view from the sociology of science'. The Sociological Review 34: 1-37.

Lave, Jean and Wenger, Etienne

(1991) Situated learning: Legitimate peripheral participation. Cambridge: Cambridge University Press.

Lefevbre, Henri

(1991) The production of space. Oxford: Blackwells. 
Neilson, Gary, Bruce A. Pasternack, and Decio Mendes

(2003) 'The four bases of organizational DNA: Strategy + business magazine. New York: Booz, Allen, Hamilton.

Onyx, Jenny and Leonard, Rosemary

(2001) Social capital: The relative use of strong and loose network ties. Lindfield, NSW, Australia: Centre for Australian Community Organizations and Management.

Paulsen, Neil, and Tor Hernes

(2004) Managing boundaries in organizations: Multiple perspectives. Basingstroke: Palgrave Macmillan.

Rose, Nikolas

(1996) Inventing our selves: Psychology, power and personhood. Cambridge: Cambridge University Press.

Rudd, Kevin

(2009) 'The global financial crisis', The Monthly: Australian Politics, Society and Culture. Accessed at http://www.themonthly.com.au/monthly-essays-kevin-rudd-globalfinancial-crisis--1421, 09.09 .09

Schultz, Theodore W. 
(1971) Investment in human capital: The role of education and research. New York: Free Press.

Schutz, Alfred

(1967) The Phenomenology of the social world. USA: Northwestern University Press.

Stewart, Thomas A.

(1997) Intellectual Capital: The new wealth of organizations. New York: Currency Doubleday.

Sveningsson, Stephan, and Mats Alvesson

(2003) 'Managing managerial identities: Organizational fragmentation, discourse and identity struggle’. 2003/1 Institute of Economic Research Working Paper Series. Lund: Sweden.

Thompson, Michael

(2008?) Organising and disorganising: A dynamic and non-linear theory of institutional emergence and its implications. Axminister: Triarchy Press.

Thurow, Lester C.

(1970) Investment in human capital. Belmont, California: Wadsworth Pub Co.

Watson, James, and Francis Crick 
(1953) ‘A structure for deoxyribose nucleic acid’. Nature 171: 964-967.

Wenger, Etienne

(1998) Communities of practice: Learning, meaning and identity. Cambridge: Cambridge University Press.

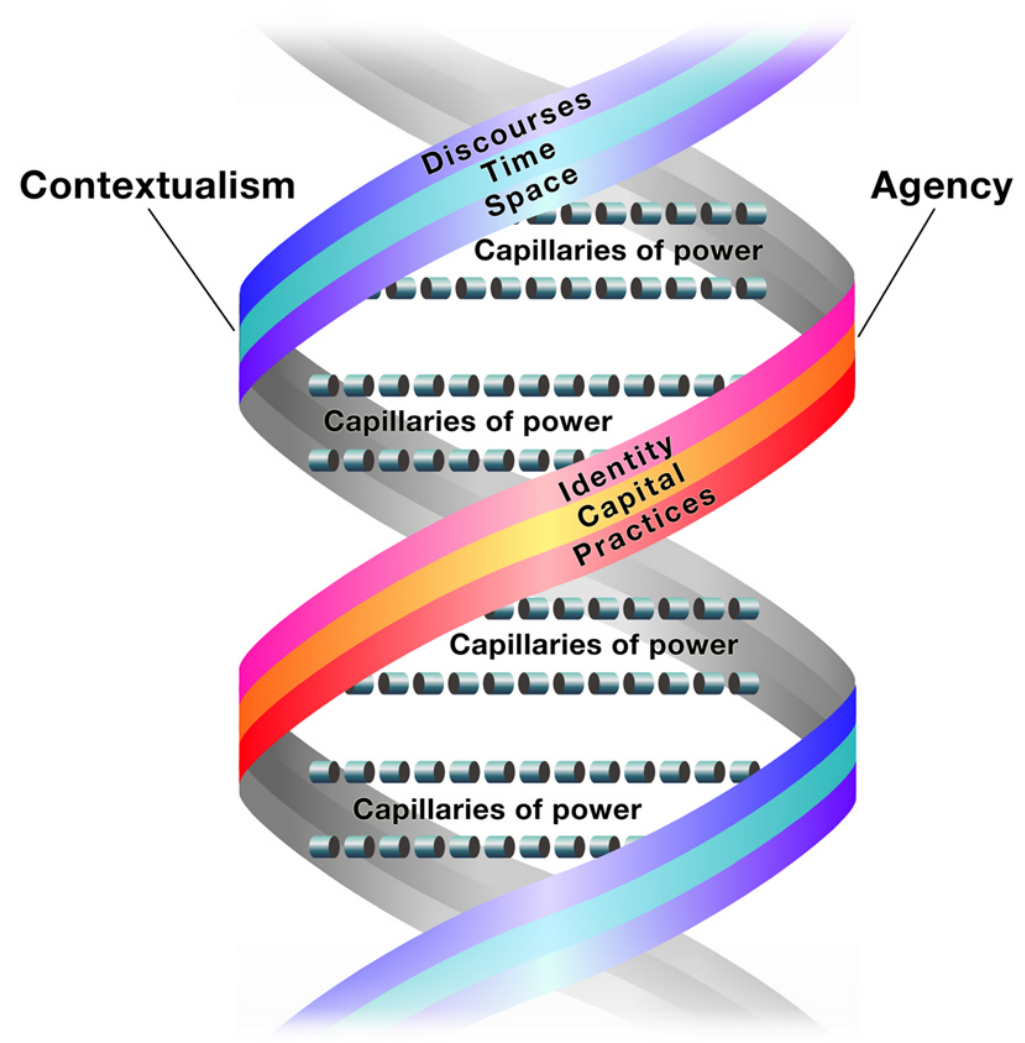

Figure 1: The DNA of Socially Organized Life 


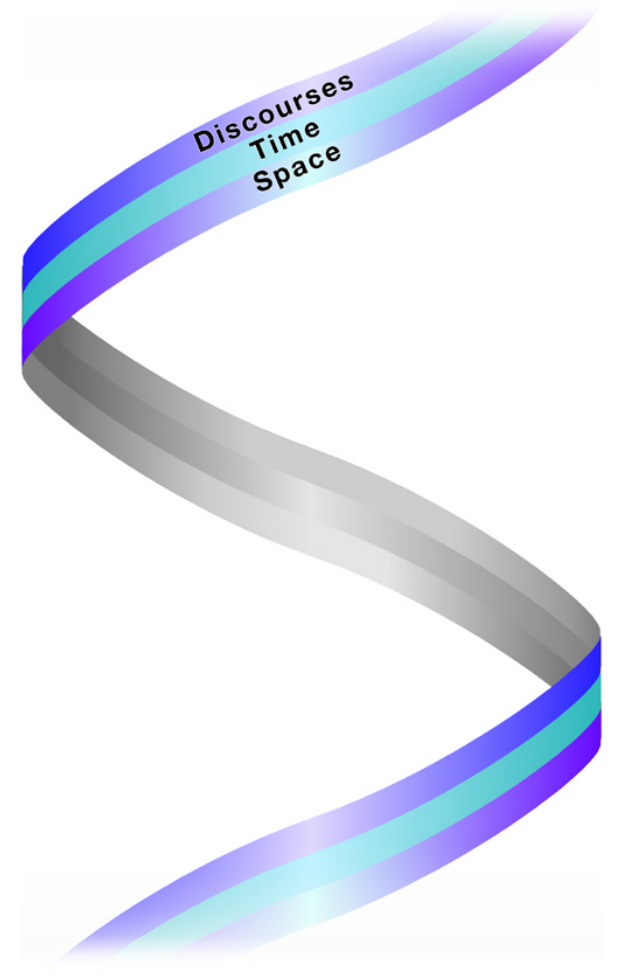

Map 1: Contextualism 


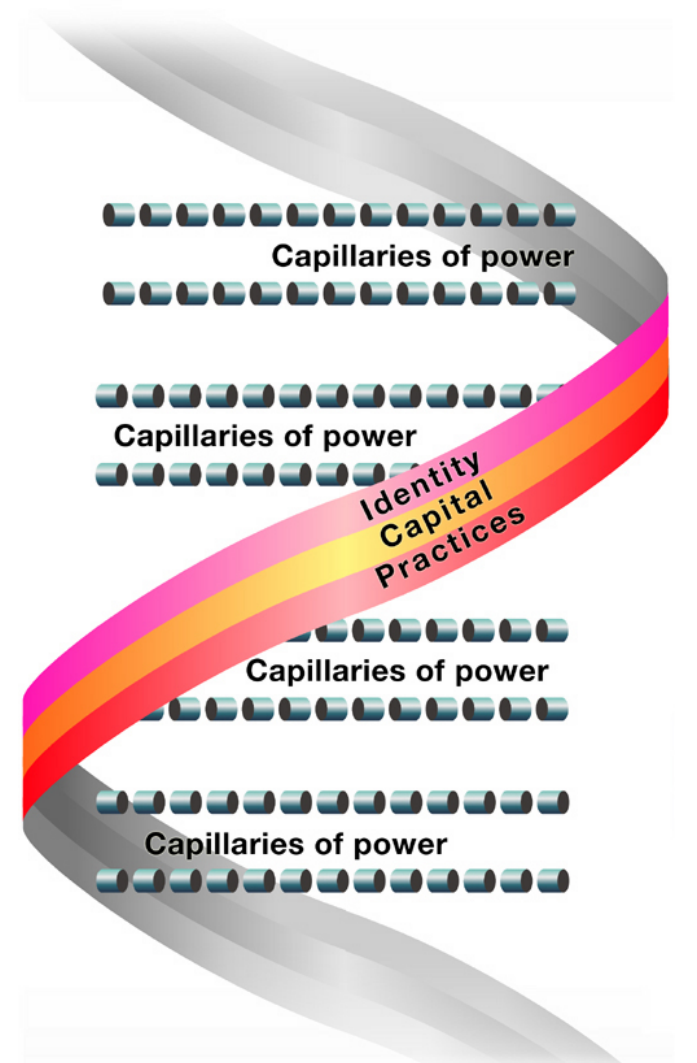

Map 2: Agency 